\title{
BIOFERTILIZERS AND COMPOSTING ACCELERATORS OF POLLUTING MACROPHYTES OF A COLOMBIAN LAKE
}

\author{
Patricia Martínez-Nieto ${ }^{1 *}$ Jaime Bernal-Castillo $^{2}$, Mercedes Calixto-Díaz ${ }^{2}$, María \\ Angélica Del Basto-Riaño ${ }^{2}$, and Beatriz Chaparro-Rico ${ }^{1}$ \\ ${ }^{1}$ Corporación Autónoma Regional de Cundinamarca. Bogotá, Colombia, (Cundinamarca - \\ Colombia). ${ }^{2}$ Facultad de Ciencias, Pontificia Universidad Javeriana \\ Carrera 7 No. 43-82, Bogotá, Colombia. \\ *Corresponding autor: patingli@yahoo.com
}

\begin{abstract}
Composting of the macrophytes Eichhornia crassipes (water hyacinth) and Egeria densa (Brazilian elodea) has been proposed as a final disposal, following their mechanical removal in the lake Fúquene (Ubaté, Cundinamarca). Microorganisms, isolated and selected by antagonism, were evaluated as inoculants to accelerate the composting and to stimulate plant growth. In microbial biopreparations of bacteria, actinomycetes and fungi, maximum amylolytic activities were found of $2,422 \mathrm{U} \mathrm{L}^{-1}$, $1,744 \mathrm{U} \mathrm{L}^{-1}$ and $1,426 \mathrm{U} \mathrm{L}^{-1}$, respectively; cellulolytic activities of $233.2 \mathrm{U} \mathrm{L}^{-1}, 668 \mathrm{U} \mathrm{L}^{-}$ ${ }^{1}$ and $701.4 \mathrm{U} \mathrm{L}^{-1}$ and proteolytic activities of $660 \mathrm{U} \mathrm{mg}^{-1}, 520 \mathrm{U} \mathrm{mg}^{-1}$ and $400 \mathrm{U} \mathrm{mg}^{-1}$. In test of these biopreparations in windrow composting of aquatic macrophytes waste, the best result was obtained with a concentration of $2 \%$. The assay conducted on seedlings of radish (Raphanus sativus $\mathrm{L}$ ) under greenhouse conditions $(P<0.05)$, using the following treatments: microbial inoculants, compost inoculated to $2 \%$, pure or mixed with soil (1:1), peat $50 \%$ and chicken manure at $33 \%$ mixed with soil, showed that actinomycetes stimulated plant growth significantly, as did chicken manure and bacteria. Microbial inoculants role for growth, development and nutrients assimilation in radish, was evident, and also for accelerating polluting macrophytes composting process.
\end{abstract}

Keywords: Composting, microbial inoculants, biomanure, biofertilizers, submerged fermentation.

\section{INTRODUCTION}

Lake Fúquene (Cundinamarca, Colombia), has massive proliferation of aquatic plants especially water hyacinth (Eichhornia crassipes) and Brazilian Elodea (Egeria densa). This, coupled with other factors, has contributed to eutrophication, desiccation and progressive deterioration of the environmental conditions of the lake ecosystem (Andrade and Franco, 2007). As a control and useful technique, the macrophytes is harvested by mechanical means and subjected to composting (Quintero and Otero, 2006; Consejo Nacional de Política Económica y Social, República de Colombia, 2006). In 1999, the Japan International Cooperation Agency (JICA) and the Corporación 
Autónoma Regional de Cundinamarca (CAR), obtained compost from Brazilian elodea, water hyacinth and rushes, at temperature not exceeding $37^{\circ} \mathrm{C}$; in 2004 , elodea and water hyacinth wastes, were degraded more effectively by inoculating mixtures of microorganisms (MartínezNieto, 2004).

The use of bacteria, actinomycetes and fungi in the decomposition of organic matter produces good results by taking advantage of their enzymatic activities, favoring the elimination of organic waste and providing beneficial metabolic products to the soil (Tiquia et al., 2002; Singh and Sharma, 2003). The enzymatic activities of these microorganisms play an important role in the degradation of complex substrates such as lignin and cellulose (Nakamura et al., 2001; Tiquia et al., 2002), which facilitates degradation of aquatic macrophytes in the composting process.

In the research reported here, microbial inoculants were prepared from microorganisms isolated from composting processes of macrophytes, water hyacinth and Brazilian elodea, in order to evaluate their enzymatic activity, the role in accelerating the degradation process and action as a plant growth promoting.

\section{MATERIALS AND METHODS}

\section{Microorganisms}

The used bacterial strains belong to the species Comamonas acidovorans, Sphingomonas paucimobilis, Stenotrophomonas maltophilia, Bacillus licheniformis, Pseudomonas sp, B. mycoides and Providencia sp. The Fungal were Syncephalastrum sp., Aspergillus fumigatus, A. terreus, A. flavus, A. clavatus, Aspergillus sp., Rhizopus sp., y Absidia corymbifera. The Actinomycetes fit in Actinomadura sp., Streptomyces avermistitis, Streptomyces sp., Nocardiopsis sp., Nocardiodes sp., Kineosporia sp., Pseudonocardia thermophila, Actinobispora sp., and Dactylosporangium vinareum (Figures 1a, b y c). These organisms were isolated in a process of composting mixture of water hyacinth, Brazilian elodea, bean pods and manure at rates that depended on each treatment (Martínez-Nieto, 2004) and chosen for the production of inoculants by antagonism techniques and qualitative enzymatic assays in starch agar, cellulose agar and skim-milk agar (Eslava and García, 2001; Rodríguez et al., 2002; Martínez-Nieto, 2004; Chen-Chin et al., 2009; Orji et al., 2009).

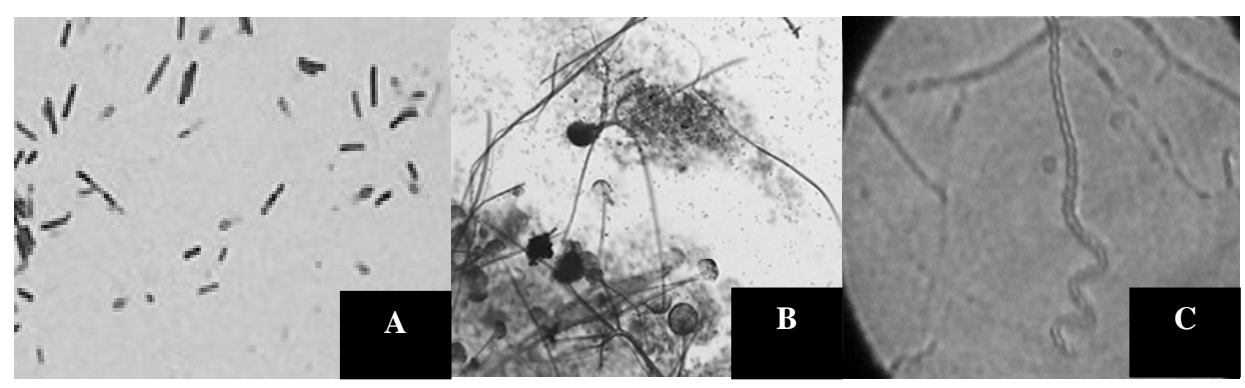

Figure 1. Microscopic features of Bacillus licheniformis (A), Absidia corymbifera (B) and Streptomyces sp. (C). 
Microbial inoculants production by Submerged Fermentation

The bacterial fermentation process was carried out in a $14 \mathrm{~L}$ bioreactor (designed by8 a Colombian company, Procesos Biotecnológicos) to produce $5000 \mathrm{~mL}$ of inoculant in liquid phase at $32{ }^{\circ} \mathrm{C}, 1 \mathrm{vvm}$ of airflow rate and $120 \mathrm{rpm}$. Fermentation of fungi and actinomycetes was performed by duplicate, in bioreactors for 5 days at $28{ }^{\circ} \mathrm{C}$ and $150 \mathrm{rpm}$, with air supplied by an aquarium air pump. In each process, substrate consumption was determined by 3,5-dinitrosalicylic acid (DNS) method (Miller, 1959), biomass formation by plate count and measurement of $\mathrm{pH}$ values.

\section{Quantitative Enzymatic Activity}

Batch fermentation were carried in 500 $\mathrm{mL}$ Erlenmeyer flasks, containing $360 \mathrm{~mL}$ of soluble starch $(1 \% \mathrm{w} / \mathrm{v})$ milk $(1 \% \mathrm{v} / \mathrm{v})$ or cellulose $(1 \% \mathrm{w} / \mathrm{v})$, with $40 \mathrm{~mL}$ of inoculum and $150 \mathrm{rpm}$ agitation during 52 $\mathrm{h}$ for bacteria, and $96 \mathrm{~h}$ for fungi and actinomycetes. Samples were taken during fermentation and inoculated on skim-milk agar, starch agar or cellulose agar for dilution plate counts; concentrations of reducing sugars were determined using the DNS method and protein content by Bradford assay (Bradford, 1976). One unit (U) of $\alpha$ amylase activity was defined as the amount of enzyme required to release one micromole of reducing sugar, expressed as glucose per minute under the assay conditions (Orji et al., 2009).

The protease activity was calculated on the proteolysis unit, equivalent to a halo of hydrolysis equal to $5 \mathrm{~mm}$ in diameter, and relating this value to the extracellular protein content, reporting to proteolysis specific activity as units per milligram of protein (Bradford, 1976). One unit of Carboxymethyl cellulase activity was defined as the amount of enzyme releasing one micromole of reducing sugar, as glucose, from the substrate (carboxymethyl cellulose) per minute under standard assay conditions (Chen-Chin et al., 2009).

\section{Water hyacinth and Brazilian elodea Composting}

The composting process was carried out in a farm located at the town of Nemocón (Cundinamarca, Colombia). Ten piles were mounted ( 5 treatments and their repetitions) of $82 \mathrm{~kg}$ each, made up of a mixing of elodea $(21 \mathrm{~kg})$, water hyacinth $(42 \mathrm{~kg})$, husk of rice $(2 \mathrm{~kg})$, pea and bean pods $(9 \mathrm{~kg})$, molasses $(500 \mathrm{~g})$, lime (500 g) and soil (7 $\mathrm{kg})$. Previously, the Brazilian elodea and water hyacinth were cut to obtain a particle size close to $3 \mathrm{~cm}$. Microbial inoculants were added to the first three treatments, T1, T2 and T3, and their repetition, until a final concentration of $1 \%, 2 \%$ and $0.5 \%$ respectively. In T4 treatments additions were of $750 \mathrm{~mL}$ of sterile liquid culture medium used in the preparation of the inoculants; and in the T5 controls no inoculation was made. During the composting the temperature and humidity were controlled every third day, while $\mathrm{pH}$, bacteria, actinomycetes and fungi counts were weekly. At the end of the process, an evaluation was made of the Carbon/Nitrogen ratio $(\mathrm{C} / \mathrm{N})$, dry matter percentage, moisture content, reduction of organic matter, foreign matter, germination of radish seeds (Phytotoxicity test) and human pathogenic organisms content (Escherichia coli and Salmonella sp.) (Ge et al., 2006).

\section{In vivo assay to determine the plant growth-stimulating ability}

The microbial inoculants and compost that showed the best result were tested as a vegetable growth-stimulant on radish 
plant, using a completely random design, with seven treatments, two replicates and four experimental units per replicate, for a total of 56 experimental units (Table 1).

Table 1. Treatments used in the completely random design.

\begin{tabular}{|c|c|}
\hline Treatment & Description \\
\hline $\mathrm{T} 1$ & T2 Compost \\
\hline $\mathrm{T} 2$ & T2 Compost + Soil $(1: 1)$ \\
\hline $\mathrm{T} 3$ & $\begin{array}{c}\text { Soil }+5 \mathrm{~mL} \text { bacterial } \\
\text { inoculant }\end{array}$ \\
\hline $\mathrm{T} 4$ & $\begin{array}{l}\text { Suelo }+5 \mathrm{~mL} \text { fungi } \\
\text { inoculant }\end{array}$ \\
\hline $\mathrm{T} 5$ & $\begin{array}{l}\text { Suelo }+5 \mathrm{~mL} \text { de } \\
\text { actinomycetes inoculant }\end{array}$ \\
\hline T6 & Soil + Canadian peat $(1: 1)$ \\
\hline $\mathrm{T} 7$ & $\begin{array}{c}\text { Soil }+ \text { chicken manure at } \\
33 \%\end{array}$ \\
\hline
\end{tabular}

The vegetable parameters evaluated were aerial dry weight, foliar area, bulb weight, bulb formation percentage and total nitrogen content in the substrates and plants. Radish seedlings were obtained from seeds and transplanted, when they reached an average height of $5 \mathrm{~cm}$, in plastic bags with $300 \mathrm{~g}$ of the substrates according to the different treatments. Five $\mathrm{ml}$ of microbial inoculants were added for each experimental unit, with the highest concentration obtained for each functional group in the fermentation process, according to treatment (Table 1). For controls, Canadian peat was used (supplier: Naturpaipa LTDA) mixed with soil in $1: 1$ ratio and soil with chicken manure $\quad 33 \%$ mixture (supplier: Homecenter Sodimac, Bogotá). The data were treated statistically by one-way analysis of variance (ANOVA) $(p<0.05)$ and Duncan's multiple-range test, to determine significant differences between the means. For the interpretation of the results, the percentages of bulb formation and nitrogen assimilation were transformed using the formula $\mathrm{Y}=\sqrt[2]{x+0.5}$, where, $\mathrm{Y}$ are the transformed values, and $\mathrm{x}$ are the percentages data obtained in the experiment, to reduce the coefficient of variation and detect significant differences (Orozco and Thienhaus, 1997).

\section{RESULTS AND DISCUSSION}

\section{Microbial inoculants production by Submerged Fermentation}

The highest bacterial growth rate was obtained at $24 \mathrm{~h}$ with $2 \times 10^{12} \mathrm{CFU} \mathrm{mL} \mathrm{mL}^{-1}$. Best biomass formation occurred at $80 \mathrm{~h}$ for actinomycetes with $3 \times 10^{16} \mathrm{CFU} \mathrm{mL}^{-}$ ${ }^{1}$, and for fungi with $8 \times 10^{8} \mathrm{CFU} \mathrm{mL}^{-1}$. Obtained concentrations for bacteria and fungi were higher compared with those claimed in other studies (Eslava and García, 2001; Martínez-Nieto, 2004; Cariello et al., 2007) which implied bacterial counts to $10^{9} \mathrm{CFU} \mathrm{mL}^{-1}$ and fungal counts of $10^{5}$ CFU $\mathrm{mL}^{-1}$. Actinomycetes biomass found was among the reported intervals (Eslava and García, 2001; Martínez-Nieto, 2004). Appropriate populations of bacteria, fungi and actinomycetes are important in the composting process, since a higher microbial activity favors organic matter degradation and allows decomposition of complex substrates like lignin and cellulose (Singh and Sharma, 2003).

\section{Quantitative Enzymatic Activity}

Bacteria showed maximum activity of amylase production of $2,422 \mathrm{U} \mathrm{L}^{-1}$, a 12 $\mathrm{h}$, with $4 \times 10^{12} \mathrm{UFC} \mathrm{mL}^{-1}$; actinomycetes of $1,744 \mathrm{U} \mathrm{L}^{-1}$ at $72 \mathrm{~h}$ with $1 \times 10^{7} \mathrm{UFC}$ $\mathrm{mL}^{-1}$ and fungi of $1,426 \mathrm{U} \mathrm{L}^{-1}$ at $80 \mathrm{~h}$ with 
a count of $2 \times 10^{7} \mathrm{CFU} \mathrm{mL}^{-1}$; these values were high compared to reported values which are between $47 \mathrm{U} \mathrm{L}^{-1}$ and 1,038 U $\mathrm{L}^{-1}$ (Arnedo and Parrado, 2002; Sarmiento et al., 2003). Higher protease production in the bacterial inoculants $\left(660 \mathrm{UL}^{-1}\right)$, followed by actinomycetes production $\left(520 \mathrm{U} \mathrm{L}^{-1}\right)$ and fungi production $(400 \mathrm{U}$ $\mathrm{L}^{-1}$ ) was observed. This activity took place at $48 \mathrm{~h}$, for the first; at $104 \mathrm{~h}$ for second and third, with $2 \times 10^{13} \mathrm{CFU} \mathrm{mL}^{-1}$, $4 \times 10^{6} \mathrm{CFU} \mathrm{mL}^{-1}$ and $2 \times 10^{5} \mathrm{CFU} \mathrm{mL}^{-1}$, respectively. In a study with thermophilic proteolytic bacteria, isolated in a composting process of flower residues, a proteolytic activity of $1,906 \mathrm{U} \mathrm{mL}^{-1}$ at 10 $\mathrm{h}$ of discontinuous fermentation a $70^{\circ} \mathrm{C}$ was found (Rodríguez et al., 2002). Inoculants that showed highest cellulolytic activity were $701.4 \mathrm{U} \mathrm{L}^{-1}$ with fungi, at $104 \mathrm{~h}\left(4 \times 10^{6} \mathrm{CFU} \mathrm{mL} \mathrm{m}^{-1}\right)$, followed by actinomycetes with $668,1 \mathrm{U}$ $\mathrm{L}^{-1}$ at $82 \mathrm{~h}\left(3 \times 10^{6} \mathrm{CFU} \mathrm{mL} \mathrm{mL}^{-1}\right)$ and bacteria with $233.2 \mathrm{U} \mathrm{L}^{-1}$ at $32 \mathrm{~h}\left(2 \times 10^{12}\right.$ UFC $\left.\mathrm{mL}^{-1}\right)$. These results demonstrate cellulolytic capacity of fungi and actinomycetes, which are renowned as good decaying agents particularly of complex substrates (Khalid et al., 2006; Chen-Chin et al., 2009). Cellulolytic activity obtained with bacterial inocula was lower, compared with amylolytic activity. However the presence of the two enzymatic systems is a competitive advantage for residue degradation; it has been found also that the bacterial cellulolytic enzymes promote amylase activity due to starch-to-glucose hydrolysis increase (Apun et al., 2000). Maximum value obtained with actinomycetes in this study is higher compared with Ramírez and Coha study (2003) of $330 \mathrm{UI} \mathrm{L}^{-1}$ in exoglucanases. All microbial enzymatic test counts demonstrate that the activity is associated with biomass formation, since its higher concentration occurred with maximum enzymatic activity (Rua et al., 1997).

\section{Water hyacinth and Brazilian elodea composting}

Treatment T2 was the one with less duration, followed by T3, T4, T5 and T1. In $\mathrm{T} 2$, the process was reduced 10 days compared with control T5 (Table 2). Several studies have found reduction up to half time in the composting process of municipality residues using microbial inoculants (Ichida et al., 2001; Cariello et al., 2007). During decomposition process, T1 showed rainy water infiltration through the plastic container 15 days after experiment setting, which increased humidity to $85 \%$. Even though turnover was done twice a week to lower water content, this event possibly affected composting duration. High humidity percentage produces low efficacy in degradation process due to the absence of a true thermophilic phase in the upper and medium layers of the pile (Luo et al., 2008) and by limiting oxygen content, degradation takes longer (Kroner et al., 2002). At the beginning of composting humidity averaged $75 \%$, with no bad odor. At the end of the process, high humidity levels persisted $(>65 \%$, see Table 2), which made necessary to spread all the piles and turn them over every three days, to obtain values less than $35 \%$, according to the guideline for organic fertilizers (NTC 5167, Instituto Colombiano de Normas Técnicas y Certificación, ICONTEC, 2004). For composting with fiber materials, like water hyacinth, humidity ranks between $75 \%$ and $85 \%$ beginning the process are allowed (Colom, 2001; Hargreaves, 2003). The high humidity percentage and the lower-than- $1 \mathrm{~m}^{3}$ pile size, could cause low ability to reach temperatures of $55^{\circ} \mathrm{C}$ or higher during more than two days. This could be due to the incapacity at those systems to reach an adequate balance between the heat generated by microorganisms and that loss by 
conduction, convection and radiation (Cornell Waste Management Institute, 2000; Colom, 2001). The pile size used in this research is intended for demonstrative or exploratory studies so it is not recommended for industrial purposes, because bulk with lower-than- $2 \mathrm{~m}^{2}$ bases exhibit sharp fluctuations. The highest temperature obtained during composting was observed in $\mathrm{T} 2$ with a $56^{\circ} \mathrm{C}$ average and the lowest value with a less than $50^{\circ} \mathrm{C}$ en T5, (Figure 2). T2 maintained temperatures equal or higher than $55^{\circ} \mathrm{C}$ during two days (Figure 2), complying with the Canadian standards for the type $\mathrm{B}$ compost; which requires $40^{\circ} \mathrm{C}$ during 5 days with an increase up to $55^{\circ} \mathrm{C}$ for at least $4 \mathrm{~h}$ (Ge et al., 2006). However; compared with standards of Chile, Australia and Canada for compost type $\mathrm{AA}$ and $\mathrm{A}$, it did not comply with the required time, since these countries recommend that if the piling-with-manual turn-over systems is used, temperature must be higher or equal to $55^{\circ} \mathrm{C}$ during at least $72 \mathrm{~h}$, to obtain reduction of pathogens (Comisión Nacional del Medio Ambiente, Chile, 2000; Hogg et al., 2002;
Ge et al., 2006). Despite of temperatures over $55^{\circ} \mathrm{C}$ were kept only for $48 \mathrm{~h}$ in $\mathrm{T} 2$, $E$. coli was within the required ranks, and there was absence of Salmonella sp. (Table 2). Temperature and inoculated microorganisms, favored elimination of human pathogens, in contrast with the piles with sterile natural substrate (T4) and those non-inoculated (T5), in which E. coli populations were higher; besides in T5 suspicious of Salmonella sp., colonies occurred (Table 2). This results are in accordance with what was found in a composting process with cow manure, where Salmonella enteritidis an E. coli did not survived with increasing temperature higher than $45^{\circ} \mathrm{C}$ after $48 \mathrm{~h}$ and $72 \mathrm{~h}$ respectively (Lung et al., 2001). Ichida et al. (2001) observed that E. coli and Salmonella sp., found initially in poultry residues, were not detected after $4 \mathrm{~d}$ composting inoculated with a mixture of $B$. licheniformis and Streptomyces sp. Several studies indicate that pathogenic control is complex and not just the result of a thermal treatment, because in pathogen destruction from microbial

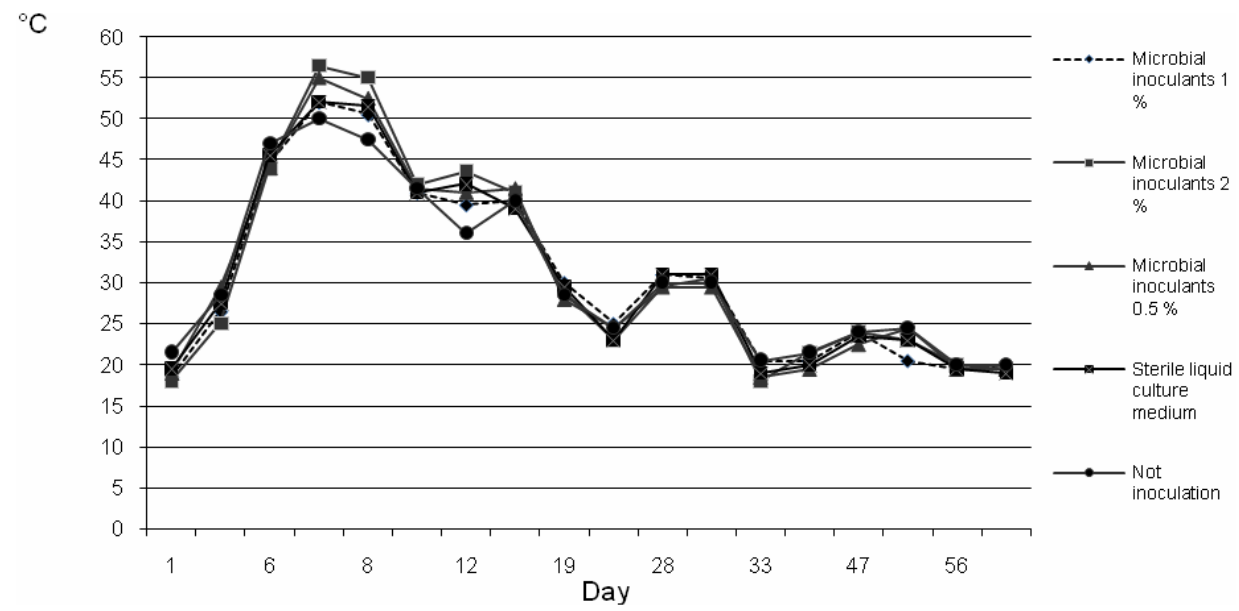

Figure 2. Temperature changes in the composting Treatments. 
competence is important and avoids recolonization when temperatures fall, either by antibiotics production, antagonism or other factors (Colom, 2001; Cornell Waste Management Institute, 2004).

The final $\mathrm{pH}$ interval in all treatments was between 7.8 and 8.4, and complying with Colombian Standard NTC 5167 (ICONTEC, 2004). However, international standards have dictated the maximum $\mathrm{pH}$ between 7.5 and 8.0 (Hogg et al., 2002; Jackson and Campbell, 2003). Microbial biomass formation was favored by addition of microbial inoculants, as the higher final concentrations indicated in $\mathrm{T} 2$ and $\mathrm{T} 3$ in comparison with the sterile substrate and non-inoculated checks, related with fungi and actinomycetes populations (Table 2). The bacterial populations found in all the treatments were high compared with studies carried out by Nakamura et al. (2001) and Moreno and Oñate (2001), in which those authors obtained maximum count between $10^{5}$ and $10^{9} \mathrm{CFU} \mathrm{g}^{-1}$; which demonstrates that nutritional conditions used in the process were appropriate. These microbial counts at the end of composting process were also high related to those established by BBC laboratories (2005) between $10^{7}$ and $10^{10} \mathrm{UFC} \mathrm{g}^{-1}$ for bacteria, $10^{3}$ and $10^{4} \mathrm{UFC}^{-1}$ for fungi and between $10^{4}$ and $10^{6} \mathrm{CFU} \mathrm{g}^{-1}$ de actinomycetes. As indicated by Czaczyk et al. (2001), inoculation effect was observed in mesophilic bacteria count, where there was a rise in microorganism number related to the non-inoculated control.

Temperature rise beyond $50^{\circ} \mathrm{C}$ in most treatment, high production of microbial biomass and lack of bad odors in this study, indicate that the prepared compound mixtures had appropriate carbon and nitrogen content, which allowed a fast use of these nutrients by the microorganisms in protein synthesis and energy obtaining for cellular division (Martínez-Nieto, 2006; Cariello et al., 2007; Abaunza et al., 2008). At the end of the process, $\mathrm{C}: \mathrm{N}$ ration fell to $12: 1$ approximately for all treatments, but for control T5 that was 9:1; this trend was according Colombian and international quality standards, that have established ratios lower than 25:1 (Hogg et al., 2002; ICONTEC, 2004; Ge et al., 2006). For some authors, a compost to be incorporated to the soil must not have a $\mathrm{C}: \mathrm{N}$ ratio below $10: 1$; to avoid high ammonia concentrations, which are generally phytotoxic (Bio-Logic Environmental System, 2001; Samudro and Hermana, 2007).

Parameters such as organic material reduction percentage, foreign matter, total coliformes, Salmonella sp. And phytotoxicity in radish, are found in the interval required in quality standard; except treatment T5, which showed two Salmonella sp. suspicious colonies and treatment $\mathrm{T} 1$, with a radish germination percentage below 90\% (Table 2). Heavy metal content was not determined in this study. Previous research analyzed these elements concentrations in Water hyacinth, Brazilian elodea, bean pods and the compost from these compounds, obtaining in all cases concentrations below the allowed limit (Martínez-Nieto, 2004).

Considering all evaluated parameters and based on Colombian, Chilean, Canadian and Australian Standards (Comisión Nacional del Medio Ambiente del Gobierno from Chile, 2000; Hogg et al., 2002; ICONTEC, 2004; Ge et al., 2006) the treatment with best results was $\mathrm{T} 2$; thus, T2 was chosen for the in vivo assay. 
Biofertilizers and composting accelerators of colombian lake macrophytes,

Martínez-Nieto et al.

Table 2. Evaluation of physicochemical and microbiological quality compost obtained in the different composting treatments.

\begin{tabular}{|c|c|c|c|c|c|c|c|}
\hline Parameter & Unit & MI $1 \%$ & MI $2 \%$ & MI $0.5 \%$ & SLCM & NI & NTC 5167 \\
\hline $\mathrm{pH}$ & & 7.9 & 7.8 & 7.9 & 8 & 8.4 & $4.0-9.0$ \\
\hline Moisture content & $\%$ & 67 & 65 & 72 & 72 & 68 & $<35$ \\
\hline Self heating & ${ }^{\circ} \mathrm{C}$ & 20 & 20 & 20 & 19 & 20 & PNR \\
\hline $\begin{array}{l}\text { Reduction } \\
\text { Organic matter }\end{array}$ & $\%$ & 61 & 67 & 68 & 60 & 69 & PNR \\
\hline $\mathrm{T}^{\circ}$ maxime & ${ }^{\circ} \mathrm{C}$ & 52 & 56 & 55 & 52 & 50 & PNR \\
\hline $\mathrm{T}^{\circ} \geq 55^{\circ} \mathrm{C}$ & $\mathrm{h}$ & 0 & 48 & 24 & 0 & 0 & PNR \\
\hline $\mathrm{T}^{\circ} 45-50^{\circ} \mathrm{C}$ & day & 8 & 8 & 8 & 7 & 7 & PNR \\
\hline Foreign matter & $\%$ & 0 & 0 & 0 & 0 & 0 & $\begin{array}{c}\text { Plastic, metal and rubber: }<2 \\
\text { Glass: Absent } \\
\text { Stone: }<2\end{array}$ \\
\hline Phytotoxicity & $\%$ & 83 & 93 & 97 & 90 & 93 & PNR \\
\hline Total Nitrogen & $\%$ & 1.54 & 1.71 & 1.48 & 1.43 & 1.59 & $>1 \%$ \\
\hline Carbon & $\%$ & 19 & 22 & 17 & 17 & 15 & $\geq 15$ \\
\hline Carbon/nitrogen ratio & & 12 & 13 & 11 & 12 & 9 & $\leq 25$ \\
\hline Organic Matter & $\%$ & 34 & 35 & 27 & 30 & 32 & PNR \\
\hline Faecal coliform & $\mathrm{CFU} \mathrm{g}{ }^{-1}$ & 6 & 3 & 2 & 15 & 156 & $<1000$ \\
\hline Salmonella sp. & $\mathrm{CFU} \mathrm{g}^{-1}$ & 0 & 0 & 0 & 0 & 2 & Undetected \\
\hline Bacteria & CFU g ${ }^{-1}$ & $1 \times 10^{16}$ & $7 \times 10^{15}$ & $7 \times 10^{15}$ & $2 \times 10^{14}$ & $1 \times 10^{14}$ & Beneficial \\
\hline Fungi & $\mathrm{CFU} \mathrm{g}^{-1}$ & $4 \times 10^{6}$ & $2 \times 10^{7}$ & 8. $\times 10^{6}$ & $7 \times 10^{6}$ & $3 \times 10^{6}$ & microorganisms \\
\hline Actinomycetes & $\mathrm{CFU} \mathrm{g}^{-1}$ & $9 \times 10^{7}$ & 4. $\times 10^{7}$ & $3 \times 10^{7}$ & $1 \times 10^{6}$ & $2 \times 10^{7}$ & count report \\
\hline Composting period & day & 70 & 54 & 62 & 68 & 64 & PNR \\
\hline
\end{tabular}

MI: Microbial inoculants; SLCM: Sterile liquid culture médium; NI: Not inoculation Tº Temperatura; PNR: Parameter is not required. 

In vivo assay to determine the plant
growth-stimulating ability

Soil inoculated with actinomycetes produced radishes with higher foliar area and weight, bulb formation percentage despues si sigue and foliar nitrogen content (Table 3). On foliar area, actinomycetes and bacteria treatment, did not show significant differences related to treatments added with chicken manure and peat. The growth longitudinal of radish in actinomycetes, fungi (lower foliar area average), peat at $50 \%$ and chicken manure at $33 \%$ treatments, it is shown in figure 3. Related to foliar biomass, treatments with higher averages and with no significant differences among them were: soil plus actinomycetes, chicken manure at $33 \%$, compost at $50 \%$, bacteria and peat $50 \%$ (Table 3 ). Only in soil with actinomycetes maximum (100\%) bulb formation was obtained. In other treatments percentages were lower. Average weight in bulb with chicken manure was of highest value, although with $50 \%$ bulb formation. Analysis of variance did not show significant differences among treatments related bulb formation percentage $(P=0.7288)$, but differences were detected on bulb weight $(P=0.0141)$ (Table 3). Actinomycetes treatment showed the highest nitrogen assimilation percentage and third percentage of this element loss in soil, while the mixture compost-soil showed the lowest nitrogen loss with 8.5\% assimilation. Soil fertilized with chicken manure showed the highest nitrogen loss with second in assimilation (Table 4), followed by treatment with bacteria. These results give an approximation of percentage of mineralized nitrogen assimilated by plants, and are of relevance since a healthier and more fertile soil is that in which the highest percentage of mineralized nitrogen from organic matter is absorbed by plants (Orozco-Jaramillo and Martínez-Nieto, 2009).

Obtained results show that bacteria and actinomycetes used in this research play an important role in nitrogen flux and plant growth promotion. Cummings et al. (2006) and Orozco-Jaramillo and Martínez-Nieto (2009) observed that inoculation of nitrogen fixing bacteria, use alone or in mixtures, increased nutrient recovering by the plant, reducing the gas loss of nitrogen fertilizers in the soil. Many microorganisms used in this study are reported as nitrogen fixers, phosphate solubilizing agents and plant growth stimulators due to the production of substances excreted to the media, among which are found phytohormones, vitamins, phospholipids, antibiotics and siderophores, among others (Páez et al., 2005; Urrego et al., 2006; OrozcoJaramillo and Martínez-Nieto, 2009; Chen-Chin et al., 2009).

In the treatments with compost could be observed the lower nitrogen loss with

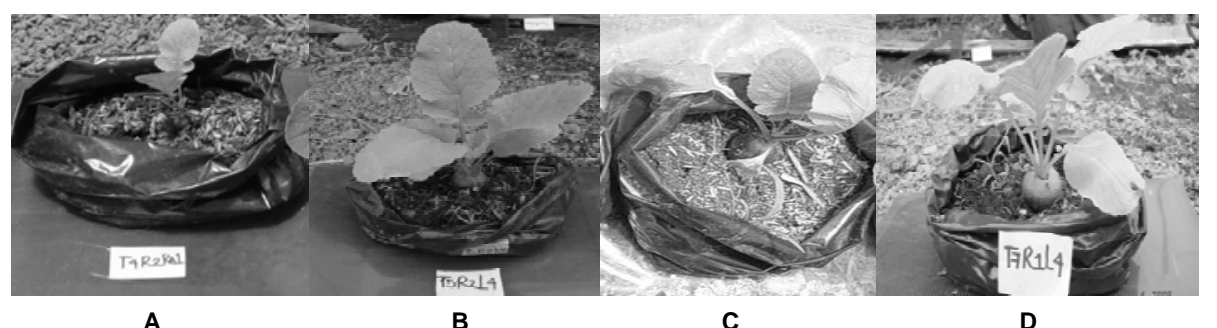

Figure 3. Radish plants growth in treatments with fungi (A), actinomycetes (B), Canadian peat (C) and chicken manure at $33 \%$ (D). 
Biofertilizers and composting accelerators of colombian lake macrophytes, Martínez-Nieto et al.

Table 3. Averages of different plant parameters evaluated in vivo radish seedlings experimental assay.

\begin{tabular}{|c|c|c|c|c|c|c|}
\hline Treatment & $\begin{array}{c}\text { Foliar area } \\
\left(\mathrm{cm}^{2}\right) * \\
P=0,002\end{array}$ & $\begin{array}{c}\text { Foliar biomass } \\
\text { (g) } * P=0,015\end{array}$ & $\begin{array}{c}\text { Bulb weight } \\
\text { (g) } * \\
P=0,014\end{array}$ & $\begin{array}{c}\text { Bulb } \\
\text { formation } \\
(\%)^{*} \\
P=0,729\end{array}$ & $\begin{array}{c}\text { Foliar nitrogen } \\
\text { (g) } * \\
P=0,022\end{array}$ & $\begin{array}{c}\text { Total nitrogen } \\
\text { substrate } \\
(\mathrm{g}) * P=\mathbf{0 , 0 0 1}\end{array}$ \\
\hline T2 Compost & 33.4 & 5.14 & 1.84 & 37.5 & 0.158 & 2.46 \\
\hline & b, $\mathbf{c}$ & b, $\mathbf{c}$ & b & & b, $\mathbf{c}$ & $\mathbf{a}$ \\
\hline T2 Compost: Soil & 43 & 9.84 & 4.81 & 62.5 & 0.345 & 1.89 \\
\hline$(1: 1)$ & b, $\mathbf{c}$ & $\mathbf{a}$ & b & & $\mathbf{a}, \mathbf{b}$ & b \\
\hline Soil $+5 \mathrm{~mL}$ & 149.8 & 9.63 & 1.25 & 62.5 & 0.375 & 1.41 \\
\hline bacterial inoculant & $\mathbf{a}$ & $\mathbf{a}$ & b & & $\mathbf{a}, \mathbf{b}$ & c \\
\hline Suelo $+5 \mathrm{~mL}$ fungi & 8.7 & 1.15 & 0.73 & 37.5 & 0.029 & 1.92 \\
\hline inoculant & C & C & b & & C & b \\
\hline Suelo + $5 \mathrm{~mL}$ & 153,5 & 14.87 & 2.93 & 100.0 & 0.502 & 1.35 \\
\hline $\begin{array}{l}\text { actinomycetes } \\
\text { inoculant }\end{array}$ & $\mathbf{a}$ & $\mathbf{a}$ & $\mathbf{b}$ & & $\mathbf{a}$ & c, $\mathbf{d}$ \\
\hline Soil + Canadian peat & 90.1 & 6.61 & 2.95 & 62.5 & 0.275 & 1.92 \\
\hline$(1: 1)$ & $\mathbf{a}, \mathbf{b}$ & $a, b, c$ & b & & $\mathbf{a}, \mathbf{b}$ & $\mathbf{b}$ \\
\hline Soil + chicken & 150.4 & 12.41 & 10.47 & 50.0 & 0.445 & 1.08 \\
\hline manure at $33 \%$ & $\mathbf{a}$ & $\mathbf{a}$ & $\mathbf{a}$ & & $\mathbf{a}$ & d \\
\hline
\end{tabular}

The amount of substrate was $300 \mathrm{~g}$ according to treatment.

*The data represent averages of three replicates. Values with different letters show significant difference as determined by Duncan's Multiple Range Test $(p<$ $0.05)$. 
J. Soil Sci. Plant Nutr. 11 (2): 47 - 61 (2011)

Table 4. Average percentages of assimilation and loss of nitrogen from in vivo assay.

\begin{tabular}{|c|c|c|c|c|c|c|c|}
\hline \multirow{3}{*}{ Treatment } & \multirow{3}{*}{$\begin{array}{l}\text { Foliar } \\
\text { biomass } \\
\text { (g) }\end{array}$} & \multicolumn{3}{|c|}{ Nitrogen (g) } & \multirow{3}{*}{$\begin{array}{l}\text { Assimilation \% } \\
*(P=0,009)\end{array}$} & \multirow{3}{*}{$\begin{array}{c}\text { Retention in } \\
\text { soil } \\
\%\end{array}$} & \multirow{3}{*}{$\begin{array}{c}\text { Loss } \\
\%\end{array}$} \\
\hline & & \multicolumn{2}{|c|}{ Substrate } & \multirow{2}{*}{ Foliar } & & & \\
\hline & & Initial & End assay & & & & \\
\hline T2Compost & 5.14 & 5.1 & 2.46 & 0.158 & 3.1 & 48.1 & 48.8 \\
\hline T2 Compost: Soil (1:1) & 9.84 & 4.1 & 1.89 & 0.345 & $\begin{array}{l}\text { c, d } \\
8.5 \\
\text { a, b }\end{array}$ & 46.3 & 45.2 \\
\hline $\begin{array}{l}\text { Soil }+5 \mathrm{~mL} \text { bacterial } \\
\text { inoculant }\end{array}$ & 9.63 & 4.5 & 1.41 & 0.375 & $\begin{array}{l}8.3 \\
\text { a, b }\end{array}$ & 31.3 & 60.3 \\
\hline $\begin{array}{l}\text { Suelo }+5 \mathrm{~mL} \text { fungi } \\
\text { inoculant }\end{array}$ & 1.15 & 4.5 & 1.92 & 0.029 & $\begin{array}{c}0.6 \\
\mathbf{d}\end{array}$ & 42.7 & 56.7 \\
\hline $\begin{array}{l}\text { Suelo }+5 \mathrm{~mL} \\
\text { actinomycetes inoculant }\end{array}$ & 14.87 & 4.5 & 1.35 & 0.502 & $\begin{array}{c}11.2 \\
\mathbf{a}\end{array}$ & 30.0 & 58.8 \\
\hline Soil + Canadian peat $(1: 1)$ & 6.61 & 4.6 & 1.92 & 0.275 & $\begin{array}{l}6.0 \\
\mathbf{b}, \mathbf{c}\end{array}$ & 41.8 & 52.2 \\
\hline $\begin{array}{l}\text { Soil + chicken manure at } \\
33 \%\end{array}$ & 12.41 & 4.5 & 1.08 & 0.445 & $\begin{array}{c}9.9 \\
\mathbf{a}\end{array}$ & 24.0 & 66.1 \\
\hline
\end{tabular}

The amount of substrate was $300 \mathrm{~g}$ according to treatment

*The data represent averages of three replicates. Values with different letters show significant difference as determined by Duncan's Multiple Range Test $(p<$ $0.05)$. 
variable assimilation. In the case of plants that grew with compost at $50 \%$, the assimilation was good and there were not significant differences with treatments: actinomycetes, chicken manure and bacteria; in contrast for $100 \%$ compost treatment, plants assimilated a low percentage of present-in-substrate nitrogen (Table 4).

Some researchers when adding compost to the soil, observed initial immobilization of nitrogen followed by strong mineralization of this element. This phenomenon occurred between week 2 and 8 after compost was added, depending on soil type. Nitrate loss due to lixiviation is low compared with the amount of nitrogen added to the soil (Burgos et al., 2006; Deenik, 2006). Another factor that could influence nitrogen absorption, when $100 \%$ compost was used as substrate, is electric conductivity, that was high according to Martínez-Nieto (2004) (13.6-19.1 dSm${ }^{-1}$ ), not allowing a good water and nutrient absorption, mainly in sensible-to-salinity plants like vegetables (Sullivan and Miller, 2004; De Gracia et al., 2006).

Plants grown in the mixture soilcompost $(1: 1)$ exhibit best records of all plant parameters compared with those grown in only-compost; this case did not show significant differences with treatments of higher averages in aerial biomass and nitrogen foliar (Table 3), according to Ozores-Haptom and Asmad reports (2010), who found negative results in vegetable growth when substrate was $100 \%$ compost; specially if it contained high values of soluble salts or if compost was still unstable. Best results were attained when peat was partially replaced by compost between $18 \%$ and $52 \%$.

It is important to compare results in compost with those in peat; the latter substrate is the most used material in plantings for the Horticulture Industry (De Gracia et al., 2006). Treatment with
$50 \%$ compost, did not show significant differences in most plant parameters, with plants grown in $50 \%$ peat, with the exception of foliar area (Table 3); this results coincide with those found for different vegetables produced at industrial scale in compost mixed with soil or other substrates, by replacing peat and vermiculite (De Gracia et al., 2006; Ozores-Haptom and Asmad, 2010).

\section{CONCLUSIONS}

Microbial inoculants role for growth, development and nutrients assimilation in radish, was evident, and also for accelerating polluting macrophytes composting process as for the case of Water hyacinth and Brazilian elodea. This due to a high enzymatic activity and probably nitrogen fixation, phosphorous solubilization or production of plant growth stimulating substances or antibiotics, promoted in the substrates by the introduced microorganisms.

\section{ACKNOWLEDGEMENTS}

To CAR (Corporación Autónoma Regional de Cundinamarca) for lending of microbial strains used in this study and to Facultad de Ciencias of Pontificia Universidad Javeriana for the use of its facilities.

\section{REFERENCES}

Abaunza, C.A., García, G., Martínez-Nieto, P., Pinto, C. O. 2008. Incorporación de prácticas agroecológicas en los principales sistemas de producción de la localidad de Santa Fe, Distrito Capital. CORPOICA, Alcaldía Mayor de Bogotá D. C., Secretaria de Gobierno, Alcaldía Local Santa Fe. Produmedios. Bogotá, Colombia, 125 $\mathrm{p}$ 
Andrade, G., Franco, L. 2007. El complejo de humedales de Fúquene, Cucunuba y Palacio. Un ecosistema estratégico bajo tensión. In: L. Franco, G. Andrade (eds). Fúquene, Cucunuba y Palacio. Conservación de la biodiversidad y manejo sostenible de un ecosistema lagunar andino. Instituto de Investigación de Recursos Biológicos Alexander von Humboldt, Fundación Humedales, Bogotá, Colombia, pp: 43-60.

Apun, K., Chian-Jong, B., Azib-Salled, M. 2000. Screening and Isolation of a cellulolytic and amylolytic Bacillus form sago pith wastes. J. Gen. Appl. Microbiol. 46, 263-267.

Arnedo, J., Parrado, G. 2002. Aislamiento y caracterización de bacterias termofílicas aerobias, con actividad amilolítica, a partir de pilas de compost en fase termofílica. Tesis pregrado Microbiología Industrial, Pontificia Universidad Javeriana, Colombia, $101 \mathrm{p}$.

BBC Laboratories. 2005. A summary guide for the microbiological analysis of soil and compost Disponible en: http://bbclas.com/function.htm Acceso: Febrero, 2006.

Bio- Logic Enviromental System. 2001. Report on assessing Compost Maturity. A final Report for the Nova Scotia Department of Environment and Labour. 49 p. Disponible en: http://www.rrfb.com/pdfs/Appendix\%20A.pdf. Acceso: Octubre, 2009.

Bradford, M. 1976. A rapid and sensitive method for quantification of microgram quantities of protein utilizing the principle of protein-DRE binding. Anal. Biochem. 72, 248254.

Burgos, P., Madejón, E., Cabrera, F. 2006. Nitrogen mineralization and nitrate leaching of a sandy soil amended with different organic wastes. Waste Manage. Res. 24, 175-182.

Cariello, M. E., Castañeda, L., Riobo, I., González, J. 2007. Inoculante de microorganismos endógenos para acelerar el proceso compostaje de residuos sólidos urbanos. J. Soil Sc. Plant Nutr. 7, 26-37.

Chen-Chin, C., Chan-Chai, N., Chung-Yi, W.,Yuan-Tay, S. 2009. Activity of cellulase from Thermoactinomyces and Bacillus spp. isolated from Brassica wates compost. Sci. Agric. 66, 304-308.

Colom, G. 2001. Compostaje de los residuos orgánicos. 16 Encuentros Estatales de amantes de la basura. Valladolid, España. 14 p. Disponible http://www.ecologistasenaccion.org/accion/residu os/ponencias.htm. Acceso: Mayo, 2009.

Comisión Nacional del Medio Ambiente del Gobierno de Chile. 2000. Norma de calidad de compost. 18 p. Disponible en http://www.lombricultura.cl/lombricultura.cl/user files/file/biblioteca/normas/Norma $\% 20$ calidad $\% 2$ 0COMPOST.pdf Acceso: Mayo, 2006.

Consejo Nacional de Política Económica y Social República de Colombia.2006. Estrategia para el manejo ambiental de la cuenca UbateSuarez. Documento CONPES 3451. Bogotá, Colombia, $53 \mathrm{p}$.

Cornell Waste Management Institute. 2000

The Science and Engineering of composting. Collage of Agriculture and Life Sciences. Ithaca, New York. Consultado 15 en. 2008. Disponible en: http://www.cfe.cornell.edu/compost/science.html. Acceso: Mayo, 2006.

Cornell Waste Management Institute. 2004 Hygienic implications of Small-scale composting in New York State. Cold compost Project. Ithaca, New York, $71 \mathrm{p}$.

Cummings, S. P., Humphry, D. R., Santos, S. R., Andrews, M., James, E. K. 2006. The potential and pitfalls of exploiting nitrogen fixing bacteria in agricultural soils as a substitute for inorganic fertilizer. Environ. Biotechnol. 2, 1-10. Disponible http://gump.auburn.edu/srsantos/pdf/Cummingset al2006EnvirBiotech.pdf. Acceso: Mayo, 2009.

Czaczyk, K., Trojanowska, K.,Stachowiak, B., Dubisz, H. 2001. Changes in cell number and ATP content during the composting process. Pol. J. Environ. Stud. 10, 149-153

Deenik, J. 2006. Nitrogen mineralization potential in important agricultural soils of Hawaii. Soil and Crop Management. SCM-15. 5 p. Disponible en http://www.ctahr.hawaii.edu/deenikj/Downloads/ SCM-15.pdf. Acceso: Junio, 2010.

De Gracia, J., Tittonel, P. A., Chiesa, A. 2006. Efecto de sustratos con compost y fertilización nitrogenada sobre la fotosíntesis, precocidad y rendimiento de pimiento (Capsicum annuum). Cien. Inv. Agr. 34, 195-204.

Eslava, M., García A. M. 2001. Evaluación de un inoculo microbiano en el proceso de degradación de residuos en cultivos de flores. Tesis pregrado Microbiología Industrial, 
Pontificia Universidad Javeriana, Colombia, 114 p.

Ge, B., Mccartney, D., Zeb J. 2006. Compost environmental protection standards in Canada. J. Environ. Eng. Sci. 5, 221-234

Hargreaves, T. 2003. The water hyacinth Disponible en: http://ecologist.testing.netgenie.co.uk/ investigations / natural_world / 82936 / the_water_hyacinth.html. Acceso: Junio, 2010.

Hogg, D., Barth, J., Favoino, E., Centemero, M., Caimi, V., Amlinger. F., Devliegher, W. Brinton, W., Antler, S. 2002. Review of Compost Standards in Australia. Banbury, Reino Unido, $11 \mathrm{p}$.

Ichida, J.M., Krizova, L., Lefevre, C. A., Keener, H. M., Elwell, D. L., Burtt, E.H. 2001. Bacterial inoculum enhances keratin degradation and biofilm formation in poultry compost. J. Microbiol Meth. 74, 199-208.

Instituto Colombiano De Normas Técnicas $Y$ Certificación (Icontec). 2004. Norma Técnica Colombiana 5167 del 2004. Productos para la industria agrícola. Productos orgánicos usados como abonos o fertilizantes y enmiendas de suelo. Ediciones ICONTEC, Bogotá, Colombia, $40 \mathrm{p}$.

Jackson, M., Campbell, A. 2003. Producing quality compost. University of New South Wales, Sydney, Australia, $71 \mathrm{p}$.

Khalid, M., Yang, W., Kishwar, N., Rajput Z., Arijo, A. 2006. Study of cellulolytic soil fungi and two nova species and new medium. J Zhejiang Univ. Sci. B. 7, 459-466. Disponible en: http://www.pubmedcentral.nih.gov/picrender.fcgi ?artid=1473997\&blobtype=pdf Acceso: Mayo, 2009

Kroner, I., Braukmeier, J., Herreklage, J., Leikam, K.,Ritzkowski, M., Schlegelmich, M., Stegmann, R. 2003. Investigation an optimization of composting processes-test systems and practical examples.Waste Management. 23,17-26.

Lung, A. J., Lin, C. M., Kim, J. M., Marshall, M. R., Nordstedt, R., Thompson, N. P., Wei, C. I. 2001. Destruction of Escherichia coli O157:H7 and Salmonella enteriditis in cow manure composting. J. Food Prot. 64, 1309-1314.

Luo, W., Chen, T.B., Zheng, G.D., Gao, D. Zhang, Y.A., Gao, W. 2008. Effect of moisture adjustments on vertical temperature distribution during forced-aeration static-pile composting of sewage sludge. Resour. Conserv. Recycling. 52, 635-642.

Martínez-Nieto, P. 2004. Evaluación de un inóculo microbiano en un proceso de compostaje con Eichhornia crassipes y Eigeria densa presentes en la laguna de Fúquene. Informe final contrato No C-0732-03. Corporación Autónoma Regional de Cundinamarca (CAR), Bogotá, Colombia, $86 \mathrm{p}$.

Martínez-Nieto, P. 2006. Compostaje de elodea, residuos de cebolla y gallinaza. In: C. Herrera, G. Sánchez, V. Peña (eds). Avances de resultados de investigación en cebolla de rama en Aquitania, Boyacá. Corporación Colombiana de Investigación Agropecuaria (CORPOICA), Corporación Autónoma Regional de Boyacá (CORPOBOYACA), Bogotá, Colombia, pp: 2740.

Miller, G. L. 1959. Use of dinitrosalicylic acid reagent for determination of reducing sugar. Anal. Chem. 31, 426-428

Moreno, G., Oñate, M. 2001. Producción de un inóculo acelerador de compostaje a partir de bacterias lipolíticas y proteolíticas aisladas del tren de tratamiento de una industria láctea. Tesis pregrado Microbiología Industrial, Pontificia Universidad Javeriana, Colombia, 144 p.

Nakamura, K., Haruta, S., Languyen, H., Ishii, M., Igarashi, Y. 2001. Enzyme production-based approach for determining the function of microorganisms within a community. Appl. Environ. Microbiol.70, 3329-3337.

Orji, J.C., Nweke, C.O., Nwabueze, R.N., Nwanyanwu, C.E., Alisi, C.S., Etin-Osowo, E.N. 2009. Production and properties of $\alpha$ amylase from Citrobacter species. Disponible en: http://www.agro.unitau.br/seer/index.php/ambiagua/article/viewFile/153. Acceso: Diciembre, 2009

Orozco-Jaramillo, C., Martínez-Nieto, P. 2009. Evaluación de la inoculación con microorganismos fijadores de nitrógeno asimbióticos aislados de la rizósfera de Pinus patula en Colombia. Bosque. 30, 70-77.

Orozco, M., Thienhaus, S. 1997. Efecto de la gallinaza en plantaciones de cacao (Theobroma cacao L) en desarrollo. Agronomía Mesoamericana. 8, 81-92.

Ozores-Hampton, M., Asmad, B. 2010. Guía para la Utilización Exitosa del Compost en la 
Producción de Hortalizas. Disponible en: http://edis.ifas.ufl.edu/pdffiles/HS/HS40600.pdf. Acceso: Junio, 2010.

Páez, M., Martínez-Nieto P., Bernal-Castillo. 2005. Siderophore producing Pseudomonas as pathogenic Rhizoctonia solani and Botrytis cinerea antagonists. Universitas Scientiarum. 10, 65-74.

Quintero, M., Otero, W. 2006. Mecanismo de financiación para promover agricultura de conservación con pequeños productores de la cuenca de la Laguna de Fúquene. Su diseño, aplicación y beneficios. Proyecto Regional Cuencas Andinas. Centro Internacional de la papa. En: http://www.infoandina.org/apc-aafiles/faa5f39cc1f1c54b7b397ea88b968260/Siste matizacion_MQuintero_WOtero.pdf.

Ramírez, P., Coha, J. 2003. Degradación enzimática de celulosa por actinomicetos termófilos: aislamiento, caracterización y determinación de la actividad celulolítica. Rev. Peru. Biol. 10, 37-77.

Rodríguez, E., Rueda, A., Pedroza, A., Poutou, R. 2002. Aislamiento, identificación y caracterización de bacterias termófilas aeróbicas, con actividad proteolítica, a partir de pilas de compost en fase termofílica. Disponible en: http://www.biologia.org/revista/pdfs/54.pdf. Acceso: Mayo, 2009

Rua, L., Wahl, C., Spraver, S., Schimid, R. 1997. Thermoalkalophic lipase of $B$ thermocatenulatus large-scale production and properties aggregation behavior and its effect on activity. J. Biotech. 56, 89-102.
Samudro, G., Hermana, J. 2007. Denitrification efficiency in a compost bed with various carbon and nitrogen content. J. Appl. Sci. Environ. Sanit. 2, 57-62.

Sarmiento, V.C., Vargas, D.H., Pedroza, A.M., Matiz, A., Poutou, R.A. 2003. Producción de $\alpha$ amilasa con células libres e inmovilizadas de Thermus sp. MVZ-Córdoba. 8, 310-317.

Singh, A., Sharma, S. 2003. Effect of microbial inocula on mixed solid wasted composting, vermicomposting and plant response. Compost Sci. and Uti.11, 190-199.

Sullivan, D.M., Miller, R. O. 2004. Propiedades cualitativas, medición y variabilidad de los compost. In: P.J. Stofella, B. A. Khan (eds). Utilización de compost en los sistemas de cultivo hortícola. Multiprensa libros S.A., Madrid, España, pp: 95-122.

Tiquia, S., Wan J., Tam, N. 2002. Microbial population dynamics and enzyme activities during composting. Compost Sci. Util.10, 150161.

Urrego-Layton, J., Rodríguez-Aponte, D., Bernal-Castillo, J., Martínez-Nieto, P. 2006. Inmovilización de bacterias diazotróficas y solubilizadoras de fósforo aisladas de un Bosque Alto Andino Cundinamarqués. In: Universidad Pedagógica y Tecnológica de Colombia (ed). Memorias Primer Congreso Nacional en Sistemas de Alta Montaña Tropical. Tunja, Boyacá, pp: 111. 